\title{
Saponin-Cholesterol-Phospholipid Adjuvant
}

National Cancer Institute

\section{Source}

National Cancer Institute. Saponin-Cholesterol-Phospholipid Adjuvant. NCI Thesaurus.

Code C53436.

An adjuvant comprised of saponin, derived from the bark of Quillaia saponaria Molina, cholesterol and phospholipid with antigen-delivery and immunostimulatory activities. This saponin-based adjuvant in combination with various antigens, including those for human papilloma virus (HPV), hepatitis C virus (HCV), and the human cancer antigen NY-ESO-1, may result in potent antibody, CD4+ T-helper-cell, and CD8+ cytotoxic T-cell responses against the targeted antigen. In addition, this agent may reduce the amount of antigen necessary to induce an efficient immune response in the host. 